\title{
Effect of disturbance on plant species abundance and density distribution in tropical forest of Sunsari district, Eastern Nepal
}

\author{
Tilak Prasad Gautam ${ }^{1 *}$ and Tej Narayan Mandal ${ }^{2}$ \\ ${ }^{1}$ Department of Botany, M.M.A.M. Campus, T.U., Biratnagar, Nepal \\ ${ }^{2}$ Department of Botany, Post Graduate Campus, T.U., Biratnagar, Nepal \\ *E-mail: tilakg673@gmail.com
}

\begin{abstract}
The disappearance of global tropical forests due to deforestation and forest degradation has reduced the biodiversity and carbon sequestration capacity. In these contexts, present study was carried out to understand the species composition and density in the undisturbed and disturbed stands of moist tropical forest located in Sunsari district of eastern Nepal. Study revealed that the forest disturbance has reduced the number of tree species by $33 \%$ and tree density by $50 \%$. In contrary, both number and density of herb and shrub species have increased with forest disturbance.
\end{abstract}

Key words: Vegetation analysis, quadrat method, Charkoshe jungle

\section{Introduction}

Tropical forests harbor the greatest wealth of biological and genetic diversity. Covering only $7 \%$ of the earth's land surface, these forests have more than half of the worlds' species (May \& Stumpf, 2000). Tropical forests comprise 52\% of total global forests. Tropical forests are mainly found in the developing countries located in neotropics (about 50\%) and South-East Asia (about 30\%).

In Nepal, 3.63 million hectares land is under natural forests which accounts for about $25 \%$ of the total land area of the country. Tropical forests in Nepal are confined to the Terai and Siwaliks, which together comprise 1878000 ha of natural forest (FRSC, 1994). The carbon stock in living forest biomass in 2010 in Nepal was $133 \mathrm{t} \mathrm{ha}^{-1}$ (FAO, 2011). About 59\% of the natural forests are broadleaved stands, $17 \%$ are conifers and $24 \%$ are mixed stands (Giri, 1996). Forest resources play an important role in the economy of Nepal and contribute $4.3 \%$ to the GDP. According to Shrestha et al. (2002), the tropical forest of Nepal includes about 487 plant species.

The forests have been sources of livelihood of many people from time immemorial. The non-timber plant resources which in most cases are much more valuable than timber resources are ignored. They increase the range of income generating options of forestdependent villagers while avoiding some of the ecological costs of timber cutting. The valuable non-timber resources of forest are edible and medicinal fruits, seeds, leafy vegetables, twigs, nuts and bark, rattan, gum, latex, tannin and dyes.

The understory vegetation is an integral part of forest ecosystems supporting a wide range of floristic diversity and providing habitats and foods for many kinds of animals. It also influence community dynamics and succession patterns and contribute to nutrient cycling. 
Disturbances lead to changes in structure and functioning of forest ecosystem. Regarding the structural changes, canopy thinning, creation of distinct canopy gaps, destruction of much of the top strata directly affect the hydrological cycle within the forest ecosystem. Disturbance also damages the functional aspects of the forest ecosystems by creating very rigorous conditions for both plant and microbial growth due to decreased organic matter content of soil, unfavorable $\mathrm{pH}$ and low nutrient supply. Disturbed forests show changes in species composition and density, stand biomass and productivity and in the patterns of nutrient cycling. Another major effect of disturbance is on species richness and diversity. The intermediate disturbance hypothesis (IDH) originally proposed by Connell (1978), predicts that diversity will be maximum at intermediate levels of disturbance.

Natural communities are inherently dynamic systems with respect to their species composition, structure and functional characteristics. The age-structure and densities of different populations constituting the communities change with time. The disappearance of tropical forests at an estimated rate of $1-2 \%$ per year comes at a time when our knowledge of their structure, composition, dynamics, diversity and taxonomy has been not fully unraveled (Hubbell \& Foster, 1983). In order to fill this lacuna, the present work was undertaken with the view to understand species abundance, and structure in terms of density in the tropical forest of eastern Nepal.

\section{Materials and Methods \\ Study area}

The study was conducted in a Sal (Shorea robusta Gaertn.) dominated moist tropical forest of Sunsari district, eastern Nepal (latitude N 26 $41^{\circ}$ to $26^{\circ} 50^{\prime}$ and longitude E $87^{\circ} 09^{\prime}$ to $87^{\circ} 21^{\prime}$ ), within the altitude range of 220 to $370 \mathrm{~m}$, msl (Fig. 1).

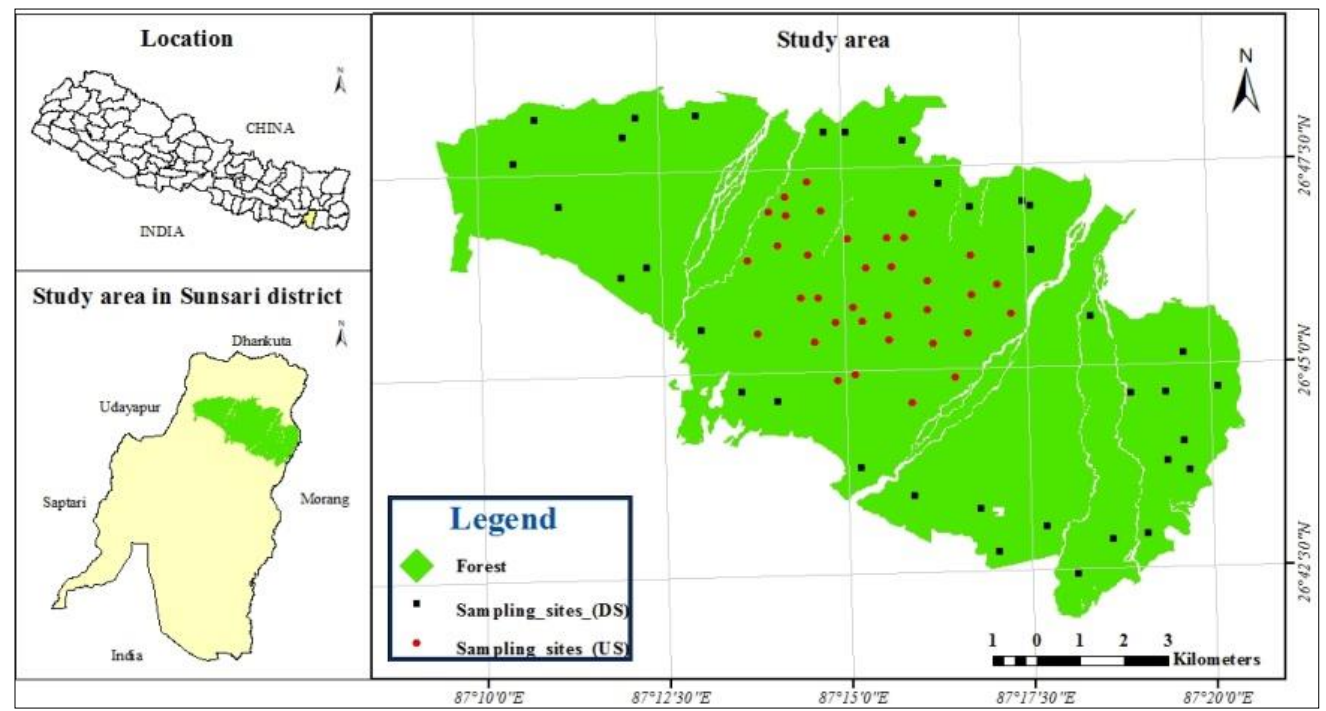

Figure 1. Map of the study area (tropical forest of Sunsari district, eastern Nepal).

The forest lies in the catchment area of Koshi River, one of the largest rivers in Nepal. The total area occupied by the forest is 11394 ha. The forest is bordered by the Siwalik hills in the north and Gangetic alluvial plain in the south. The soil mainly consists of deep alfisols. 
The climate is tropical and monsoon type with three distinct seasons: dry and warm summer (March to May), wet and warm rainy (June to October), and dry and cool winter (November to February). The mean monthly minimum and maximum air temperature during 2005-2014 ranged from 10.9 to $25.3^{\circ} \mathrm{C}$ and 22.6 to $33.2^{\circ} \mathrm{C}$, respectively. The average annual rainfall for the period was $1998.6 \mathrm{~mm}$ (Fig. 2). Pronounced rainfall occurred during the months of June to September. Relative humidity was higher in rainy season with highest value in August (92\%).

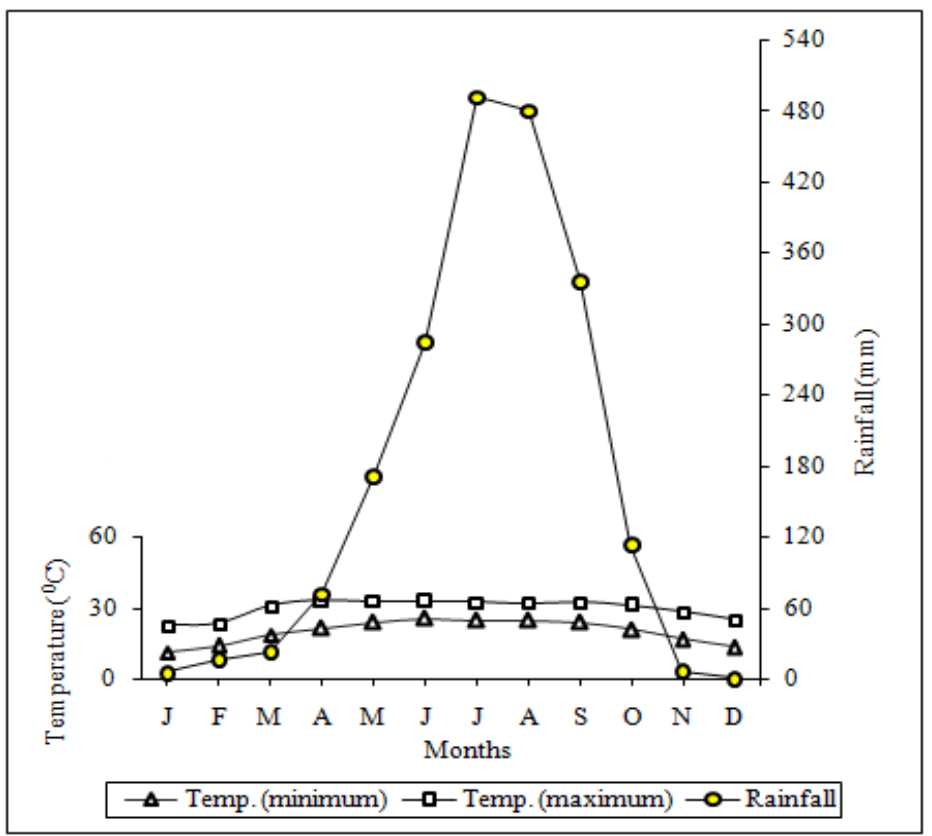

Figure 2. Ombrothermic representation of the climate of moist tropical forest region of Sunsari district, eastern Nepal. 2005-2014 (Source: Dept of Meteorology, Dharan, Nepal).

The central part (core area) of the forest is relatively undisturbed, while the peripheral part is affected by disturbance activities as removal for timber, livestock grazing, fuel-wood and litter collection, tree lopping, removal of poles for house-hold constructions and forest fires. The topstory of forest is dominated by the tropical species Shorea robusta (Dipterocarpaceae), associated with Haldina cordifolia, Careya arborea, Dillenia pentagyna, Terminalia allata, T. bellirica, T. chebula, Lagerstroemia parviflora etc. Clerodendron infortunatum, and Murraya koenigii are some of the main shrub species while Chromolaena odorata and Achyranthes aspera are dominant herbs.

\section{Sampling and vegetation analysis}

Central part of the forest was treated as undisturbed forest (UF), and peripheral part as disturbed forest (DF). Study was conducted in UF and DF stands. Altogether, seventy permanent experimental plots, thirty five each in UF and DF were randomly established. In the present study stem of tree-species having $\geq 10 \mathrm{~cm}$ girth at breast height $(\mathrm{GBH})$ were considered as trees (Lalfakawma et al., 2009). For the analysis of trees, sampling plot of 20 $\mathrm{m} \times 20 \mathrm{~m}$ was used while for shrubs nested quadrat of $5 \mathrm{~m} \times 5 \mathrm{~m}$ and for herbs nested quadrat of $1 \mathrm{~m} \times 1 \mathrm{~m}$ was established in the forest. Plant species recorded in all plots were 
identified with the help standard literatures and herbarium specimens deposited at Tribhuvan University Regional Herbarium, Post Graduate Campus, Biratnagar, Nepal. Densities of plant species present within the plots were determined.

\section{Results \\ Herb layer}

The number of herb species increased with forest disturbance. Among the total 47 species, 26 species were present in both undisturbed and disturbed forests, while 30 species were enumerated from UF and 43 species from DF (Table 1). It showed $71 \%$ similarity in the vegetation of two stands (Table 5). So, 29\% dissimilarity in the vegetation occurred due to the effect of disturbance. The four species present only in UF were Piper, Hygrophilla, Curculigo and Lygodium. Density of herbs increased with the forest disturbance (Table 1). The density values ranged between 20 and 38 individual $\mathrm{m}^{-2}$ in UF and DF, respectively.

Table 1. Density (D; individual $\mathrm{m}^{-2}$ ) of herb species in undisturbed forest stand (UF) and disturbed forest stand (DF) of moist tropical forest in Sunsari district, eastern Nepal

\begin{tabular}{lcc}
\hline \multirow{2}{*}{ Scientific names } & \multicolumn{2}{c}{ Density $\left(\right.$ Individual $\mathbf{~ m}^{\mathbf{2}}$ ) } \\
\cline { 2 - 3 } & UF & DF \\
\hline Chromolaena odorata (L.) R.M. King \& H. Rob. & 2.26 & 1.60 \\
Oplismenus compositus (L.) P. Beauv. & 3.89 & 3.20 \\
Piper longum L. & 2.26 & - \\
Commelina benghalensis L. & 1.54 & 0.77 \\
Hedychium ellipticum Buch.-Ham. ex Sm. & 0.43 & 0.09 \\
Chrysopogon aciculatus (Retz.) Trin. & 1.46 & 1.66 \\
Sonchus asper (L.) Hill & 0.06 & 0.69 \\
Sida rhombifolia L. & 0.8 & 2.06 \\
Senna tora (L.) Roxb. & 0.26 & 0.06 \\
Eclipta prostrata (L.) L. & 1.03 & 0.03 \\
Desmodium triflorum (L.) DC. & 0.49 & 1.31 \\
Kyllinga brevifolia Rottb. & 0.83 & 0.86 \\
Blumea lacera (Burm. f.) DC. & 0.51 & 0.74 \\
Paspalum scrobiculatum L. & 0.63 & 3.46 \\
Bidens bipinnata L. & 0.09 & 0.43 \\
Achyranthes aspera L. & 0.40 & 0.26 \\
Abutilon indicum (L.) Sweet & 0.26 & 1.06 \\
Hygrophila auriculata (Schumach.) Heine & 0.37 & - \\
Veronica javanica Bl. & 0.34 & 0.63 \\
Evolvulus nummularius (L.) L. & 0.37 & 1.69 \\
Cyperus rotundus L. & 0.43 & 2.49 \\
Oxalis corniculata L. & 0.37 & 1.14 \\
Hemigraphis hirta (Vahl) T. Anderson & 0.17 & 0.14 \\
Cynodon dactylon (L.) Pers. & 0.43 & 3.20 \\
Curculigo orchioides Gaertn. & 0.09 & - \\
Ageratum conyzoides L. & 0.14 & 1.69 \\
Youngia japonica (L.) DC. & 0.11 & 0.17 \\
Tridax procumbens L. & 0.09 & 0.11 \\
Centella asiatica (L.) Urb. & 0.09 & 0.31 \\
Lygodium flexuosum (L.) Sm. & 0.03 & - \\
\hline & & \\
& &
\end{tabular}




\begin{tabular}{lll}
\hline Imperata cylindrica (L.) Raeusch. & - & 3.83 \\
Mikania micrantha Kunth & - & 0.60 \\
Mimosa pudica L. & - & 0.49 \\
Eragrostis tenella (L.) P. Beauv. ex Roem. \& Schult. & - & 0.94 \\
Digitaria ciliaris (Retz.) Koeler & - & 0.94 \\
Paederia scandens (Lour.) Merr. & - & 0.09 \\
Scoparia dulcis L. & - & 0.20 \\
Boerhavia diffusa L. & - & 0.23 \\
Hedyotis corymbosa (L.) Lam. & - & 0.20 \\
Chamaesyce hirta (L.) Millsp. & - & 0.20 \\
Caesulia axillaris Roxb. & - & 0.29 \\
Alysicarpus vaginalis (L.) DC. & - & 0.11 \\
Solanum americanum Mill & - & 0.11 \\
Hemarthria compressa (L. f.) R. Br. & - & 0.14 \\
Helminthostachis zeylanica L. (Hook.) & - & 0.06 \\
Ophioglossum sp. & - & 0.06 \\
Laphangium luteoalbum (L.) Tzvelev & - & 0.03 \\
\hline Total & 20.2 & 38.4 \\
\hline
\end{tabular}

\section{Shrub layer}

Altogether, 16 species were recorded in the forest. Among them, 12 species were found in UF and 15 in DF and 11 species were common to both forests (Table 2). It showed $81 \%$ similarity between UF and DF (Table 5). So, $19 \%$ dissimilarity between two forests occurred due to effect of disturbance. A single species recorded only in UF was Jasminum sp., while 4 species like Calotropis, Jatropha, Solanum and Callicarpa were present only in DF. Density of shrubs increased with forest disturbance from 6377 to 7040 individual ha ${ }^{-1}$ (Table 2).

Table 2. Density (D; individual ha $\mathrm{ha}^{-1}$ ) of shrub species in undisturbed forest stand (UF) and disturbed forest stand (DF) of moist tropical forest in Sunsari district, eastern Nepal

\begin{tabular}{lcc}
\hline \multirow{2}{*}{ Scientific names } & \multicolumn{2}{c}{ Density (Individual ha $\mathbf{~}^{-\mathbf{1}}$ ) } \\
\cline { 2 - 3 } & UF & DF \\
\hline Murraya koenigii (L.) Spreng. & 1668.57 & 251.43 \\
Phyllanthus reticulatus Poir. & 1291.43 & 251.43 \\
Osbeckia chinensis L. & 1200 & 342.86 \\
Lantana camara L. & 1028.57 & 960 \\
Clerodendrum infortunatum L. & 445.71 & 1302.86 \\
Pogostemon benghalensis (Burm f.) Kuntze & 297.14 & 1245.71 \\
Leea aequata L. & 45.71 & 1108.57 \\
Colebrookea oppositifolia Sm. & 34.29 & 308.57 \\
Vitex negundo L. & 11.43 & 114.29 \\
Jasminum sp. & 182.86 & - \\
Rauvolfia serpentina (L.) Benth. ex Kurz & 91.43 & 22.86 \\
Desmodium confertum DC. & 80.00 & 800.00 \\
Calotropis procera (Aiton) Dryand. & - & 251.43 \\
Jatropha curcas L. & - & 11.43 \\
Solanum torvum Sw. & - & 34.29 \\
Callicarpa macrophylla Vahl & - & 34.29 \\
\hline Total & 6377 & 7040 \\
\hline
\end{tabular}




\section{Tree layer}

In the present study, 981 individuals of trees were recorded which belonged to 60 species, 51 genera, and 32 families (Table 3). Out of these, 57 species were present in UF, 38 in DF and 35 were common to both forest stands. The number of species found only in UF was 22, whereas that in DF was 3. It showed 74\% similarity between UF and DF as per the Sorenson's similarity index (Table 5). So, $26 \%$ dissimilarity between two stands reflected the consequence of disturbance.

Table 3. Enumeration of tree species found in undisturbed forest stand (UF) and disturbed forest stand (DF) in moist tropical forest of Sunsari district, eastern Nepal

\begin{tabular}{|c|c|c|c|}
\hline Scientific names & Local name/s & Families & Occurrence \\
\hline Acacia catechu (L.f.) Willd. & Khayer & Mimosaceae & Both \\
\hline Acacia ferruginea DC. & Khaur & Mimosaceae & UF \\
\hline Acer oblongum Wall. ex DC. & Phirphire & Aceraceae & UF \\
\hline Aegle marmelos (L.) Correa & Bel & Rutaceae & Both \\
\hline Alangium salviifolium (L.f.) Wangerin & Asare & Alangiaceae & Both \\
\hline Albizia julibrissin Durazz. & Rato Siris & Mimosaceae & Both \\
\hline Albizia lebbeck (L.) Benth. & Padke Siris & Mimosaceae & Both \\
\hline Albizia procera (Roxb.) Benth. & Thakar & Mimosaceae & Both \\
\hline Alstonia scholaris (L.) R. Br. & Chhatiwan & Apocynaceae & Both \\
\hline Anogeissus latifolius (Roxb. ex DC.) Bedd. & Paani Sahaj, Banjhi & Combrataceae & UF \\
\hline Baliospermum solanifolium (Burm.) Suresh & Aaulea & Euphorbiaceae & Both \\
\hline Bauhinia malabarica Roxb. & Amiltanki & Caesalpiniaceae & UF \\
\hline Bombax ceiba $\mathrm{L}$. & Simal & Bombacaceae & Both \\
\hline Bridelia retusa (L.) A. Juss. & Gayo & Euphorbiaceae & Both \\
\hline Careya arborea Roxb. & Kumbhi & Myrtaceae & Both \\
\hline Cassia fistula $\mathrm{L}$. & Raajbriksha & Caesalpiniaceae & Both \\
\hline Cassia sp. & & Caesalpiniaceae & UF \\
\hline Cordia dichotoma G. Forst. & Bohori & Cordiaceae & UF \\
\hline Cornus oblonga Wall. & Lati kath & Cornaceae & UF \\
\hline Dalbergia latifolia Roxb. & Satisal & Papilionaceae & UF \\
\hline Desmodium oojeinense (Roxb.) H. Ohashi & Sandan & Fabaceae & UF \\
\hline Dillenia pentagyna Roxb. & Tantary & Dillaniaceae & Both \\
\hline Diospyros chloroxylon Roxb. & Kalikath & Ebenaceae & UF \\
\hline Diploknema butyracea (Roxb.) H.J. Lam. & Chiuri & Sapotaceae & Both \\
\hline Ehretia laevis Roxb. & Datrungo & Cordiaceae & Both \\
\hline Elaeagnus latifolia $\mathrm{L}$. & Guyelo & Elaeagnaceae & UF \\
\hline Falconeria insignis Royle & Khirro & Euphorbiaceae & Both \\
\hline Ficus lacor Buch.-Ham. & Kavro & Moraceae & Both \\
\hline Ficus racemosa $\mathrm{L}$. & Dumri & Moraceae & Both \\
\hline Ficus rumphii Blume & Sami & Moraceae & UF \\
\hline Ficus semicordata Buch.-Ham ex Sm. & Khaniu & Moraceae & UF \\
\hline Garuga pinnata Roxb. & Dabdabe & Burseraceae & Both \\
\hline Gmelina arborea Roxb. & Khamari & Verbanaceae & UF \\
\hline Grewia optiva J.R. Drumm. ex Burret & Syalphusro & Tiliaceae & Both \\
\hline Haldina cordifolia (Roxb.) Ridsdale & Karma & Rubiaceae & Both \\
\hline Heynea trijuga Roxb. ex Sims & Aankha taruwa & Meliaceae & UF \\
\hline Holarrhena pubescens Wall. ex G. Don & Musabar & Apocynaceae & Both \\
\hline Holoptelia integrifolia Planch. & Pipari & Ulmaceae & Both \\
\hline Lagerstroemia parviflora Roxb. & Botdhayero & Lythraceae & Both \\
\hline
\end{tabular}




\begin{tabular}{llll}
\hline Lannea coromandelica (Houtt.) Merr. & Hallude & Anacardiaceae & Both \\
Mallotus pallidus (Airy Shaw) Airy Shaw & Sindure & Euphorbiaceae & UF \\
Mallotus repandus (Willd.) Mull. Arg. & Pithari & Euphorbiaceae & Both \\
Neolamarckia cadamba (Roxb.) Bosser & Kadam & Rubiaceae & DF \\
Oroxylum indicum L. Kurz & Totalo & Bignoniaceae & DF \\
Phyllanthus emblica L. & Amala & Euphorbiaceae & UF \\
Premna mollissima Roth & Gineri & Verbenaceae & UF \\
Schleichera oleosa (Lour.) Merr. & Kusum & Sapindaceae & Both \\
Semecarpus anacardium L.f. & Bhalayo & Anacardiaceae & Both \\
Shorea robusta Gaertn. & Sal & Dipterocarpaceae & Both \\
Spondias pinnata (L.f.) Kurz & Amaro & Anacardiaceae & UF \\
Sterculia villosa Roxb. & Odal & Sterculiaceae & UF \\
Stereospermum tetragonum DC. & Padari & Bignoniaceae & UF \\
Syzygium cumini (L.) Skeels & Jamun & Myrtaceae & Both \\
Syzygium nervosum A.Cunn. ex DC. & Kyamuna & Myrtaceae & Both \\
Tamarindus indica L. & Titri & Caesalpiniaceae & DF \\
Terminalia bellirica (Gaertn.) Roxb. & Barro & Combretaceae & Both \\
Terminalia chebula Retz. & Harro & Combretaceae & Both \\
Terminalia tomentosa Wight. \& Arn. & Saj, Asna & Combretaceae & Both \\
Trema orientalis (L.) Blume. & Kunyel & Ulmaceae & Both \\
Ziziphus mauritiana Lam. & Bayer & Rhamnaceae & UF \\
\hline
\end{tabular}

Table 4. Density (D; individual $\mathrm{ha}^{-1}$ ) of tree species (> $10 \mathrm{~cm} \mathrm{GBH}$ ) in undisturbed and disturbed forest stands of moist tropical forest in Sunsari district, eastern Nepal

\begin{tabular}{lcc}
\hline & \multicolumn{2}{c}{ Density (Individual ha $\mathbf{~}^{\mathbf{- 1}}$ ) } \\
\cline { 2 - 3 } & Undisturbed forest & Disturbed forest \\
\hline Shorea robusta & 100.00 & 64.29 \\
Haldina cordifolia & 39.29 & 21.43 \\
Lagerstroemia parviflora & 52.14 & 3.57 \\
Baliospermum solanifolium & 39.29 & 6.43 \\
Terminalia tomentosa & 16.43 & 15.00 \\
Alangium salviifolium & 25.71 & 19.29 \\
Schleichera oleosa & 12.14 & 12.14 \\
Dillenia pentagyna & 13.57 & 7.14 \\
Terminalia bellirica & 12.86 & 10.71 \\
Syzygium cuminii & 9.29 & 2.86 \\
Mallotus pallidus & 16.43 & - \\
Diospyros chloroxylon & 13.57 & - \\
Lannea coromandelica & 7.86 & 1.43 \\
Holarrhena pubescens & 10.71 & 0.71 \\
Bombax ceiba & 3.57 & 3.57 \\
Dalbergia latifolia & 7.86 & - \\
Alstonia scholaris & 5.00 & 2.14 \\
Mallotus repandus & 5.00 & 15.00 \\
Falconeria insignis & 4.29 & 7.14 \\
Semecarpus anacardium & 3.57 & 1.43 \\
Cassia fistula & 5.00 & 4.29 \\
Careya arborea & 4.29 & 4.29 \\
Albizia lebbeck & 7.14 & 5.71 \\
\hline
\end{tabular}




\begin{tabular}{|c|c|c|}
\hline Syzygium nervosum & 4.29 & 0.71 \\
\hline Terminalia chebula & 2.86 & 1.43 \\
\hline Desmodium oojeinense & 2.86 & - \\
\hline Garuga pinnata & 2.86 & 0.71 \\
\hline Ehretia laevis & 2.86 & 1.43 \\
\hline Sterculia villosa & 2.14 & - \\
\hline Anogeissus latifolius & 1.43 & - \\
\hline Bridelia retusa & 2.14 & 0.71 \\
\hline Albizia procera & 0.71 & 1.43 \\
\hline Grewia optiva & 2.14 & 0.71 \\
\hline Cassia sp. & 2.14 & - \\
\hline Ficus lacor & 1.43 & 0.71 \\
\hline Bauhinia malabarica & 1.43 & - \\
\hline Heynea trijuga & 1.43 & - \\
\hline Acer oblongum & 1.43 & - \\
\hline Acacia ferruginea & 1.43 & - \\
\hline Ficus rumphii & 1.43 & - \\
\hline Acacia catechu & 2.14 & 0.71 \\
\hline Albizia julibrissin & 0.71 & 0.71 \\
\hline Cordia dichotoma & 1.43 & - \\
\hline Premna mollissima & 1.43 & - \\
\hline Cornus oblonga & 1.43 & - \\
\hline Trema orientalis & 1.43 & 0.71 \\
\hline Spondias pinnata & 0.71 & - \\
\hline Aegle marmelos & 0.71 & 7.86 \\
\hline Diploknema butyracea & 0.71 & 1.43 \\
\hline Elaeagnus latifolia & 0.71 & - \\
\hline Ficus racemosa & 0.71 & 1.43 \\
\hline Ficus semicordata & 0.71 & - \\
\hline Stereospermum tetragonum & 0.71 & - \\
\hline Ziziphus mauritiana & 0.71 & - \\
\hline Gmelina arborea & 0.71 & - \\
\hline Holoptelia integrifolia & 0.71 & 0.71 \\
\hline Phyllanthus emblica & 0.71 & - \\
\hline Neolamarckia cadamba & - & 0.71 \\
\hline Oroxylum indicum & - & 2.14 \\
\hline Tamarindus indica & - & 1.43 \\
\hline Total & 466.4 & 234.3 \\
\hline
\end{tabular}

Table 5. Sorenson's similarity indices in different growth forms of vegetation between undisturbed and disturbed forest stands in moist tropical forest of Sunsari district, eastern Nepal

\begin{tabular}{ccc}
\hline Growth forms & Similarity (\%) & Dissimilarity (\%) \\
\hline Trees & 74 & 26 \\
Shrubs & 81 & 19 \\
Herbs & 71 & 29 \\
\hline
\end{tabular}

The proportions of family to species and genera to species were higher in UF whereas the proportion of family to genera was same in both forests (Table 6). 
Table 6. Ratio of species, genus and family in undisturbed and disturbed forest stands of moist tropical forest in Sunsari district, eastern Nepal

\begin{tabular}{lccc}
\hline Forest types & Family: Species & Genus: Species & Family: Genus \\
\hline Undisturbed & 1.78 & 1.19 & 1.50 \\
Disturbed & 1.73 & 1.15 & 1.50 \\
\hline
\end{tabular}

Plant community structure in terms of density has been compared between undisturbed and disturbed forests. The UF had higher density of trees (466 trees ha ${ }^{-1}$ ) as compared to DF (234 trees ha ${ }^{-1}$ ) (Table 4, Figs. 3-4). The density of trees varied greatly in both forests ranging from 1-100 trees ha ${ }^{-1}$. In UF, the density ranged from 1 trees ha ${ }^{-1}$, each for thirteen species (22.8\% species) to 100 trees $\mathrm{ha}^{-1}$ for Shorea robusta (1.8\% species) (Fig. 3).

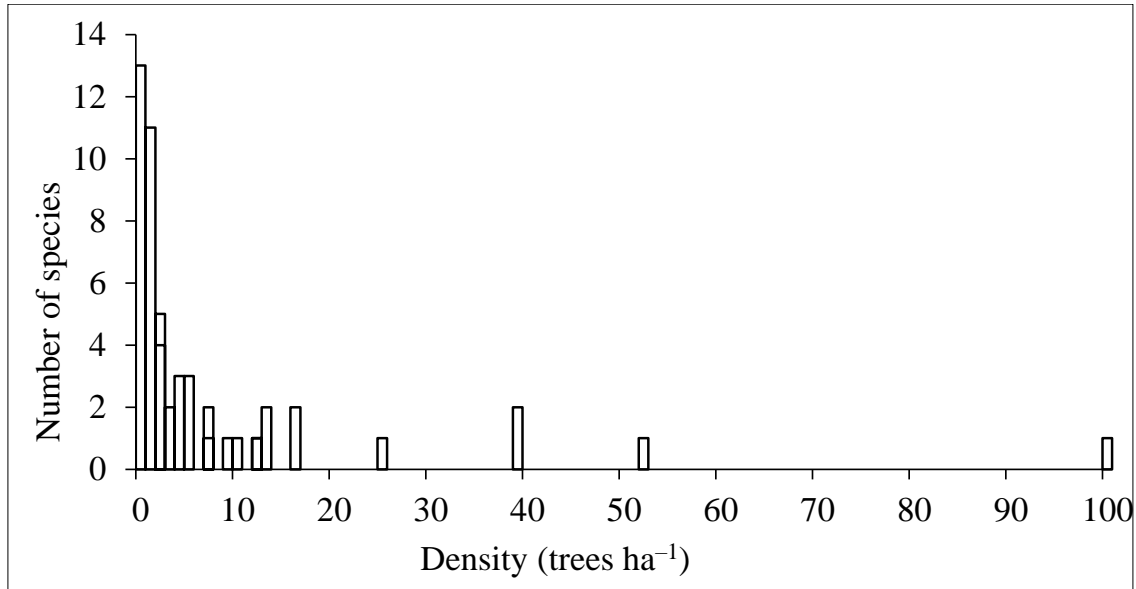

Figure 3. Species individual relationships of tree species in undisturbed forest stand of moist tropical forest in Sunsari district, eastern Nepal

The density value for disturbed forest was one tree $\mathrm{ha}^{-1}$, each for eleven species $(28.9 \%)$ and 64 for Shorea robusta (2.6\% species) (Fig. 4). Based on density value, the second dominant species was Haldina cordifolia with 39 trees ha ${ }^{-1}$ in UF and 21 trees ha $^{-1}$ in DF.

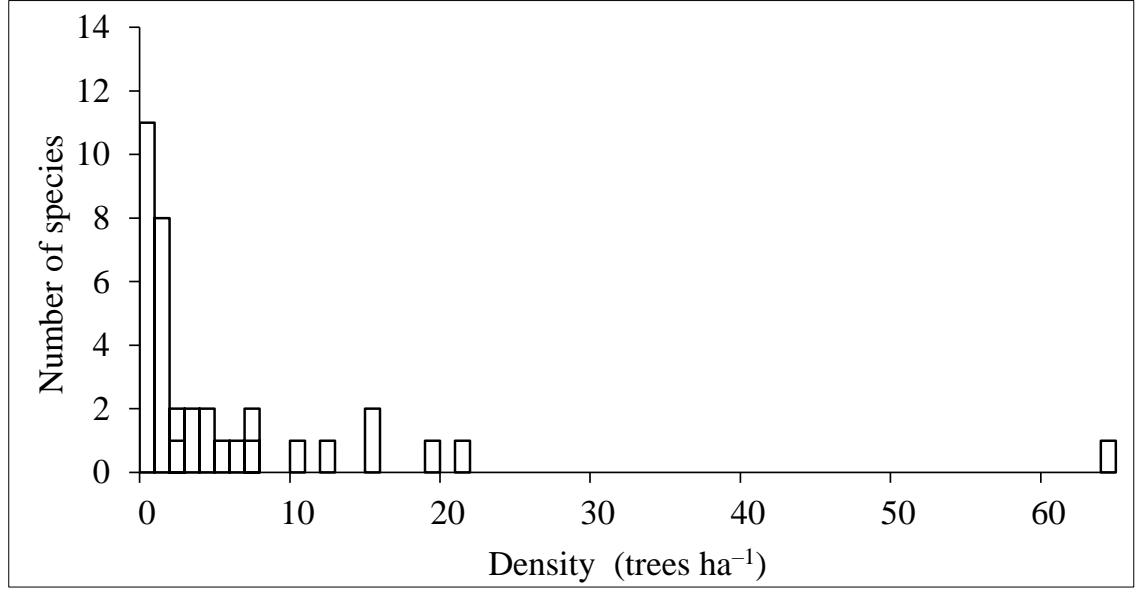

Figure 4. Species individual relationships of tree species in disturbed forest stand of moist tropical forest in Sunsari district, eastern Nepal 


\section{Discussion \\ Herb and Shrub layer}

Forest disturbances resulted in the formation of fragmented, exposed, and nutrient poor sites, awaiting recolonization. Colonization on disturbed site by successional species generally occurs through stump, root and rhizome sprouts and through seeds. Both herb and shrub species were higher in number in DF which may be due to edge effect and open canopy favoring light loving plants. On the other hand, lower number of species in UF could be attributed to the dense canopy of trees which tended to suppress the undergrowth from obtaining sufficient sunlight required for germination, growth and development in light loving species.

So far Sorenson's similarity is concerned herbs and shrubs in DF showed 19-29\% dissimilarity with the UF, which reflects the consequence of disturbance. Among the total species, 26 herb and 11 shrub species were present in both forest stands. High species overlap between UF and DF can be explained in part by their intactness, similarity in structure and their position on the landscape, and similar geography.

Oplismenus compositus, an annual herb of family Poaceae was dense in UF (4 individual $\mathrm{m}^{-2}$ ) while Imperata cylindrica was dense in DF (4 individual $\left.\mathrm{m}^{-2}\right)$. It may be due to their light weight seeds easily dispersed by wind. Among the shrubs, Murraya koenigii was dominant as per the density value in UF. It may be due to its shade and moisture loving nature. In DF, Clerodendrum infortunatum was dense. It may be associated with its high proliferation capacity in less fertile soil. Herb and shrub species content and their density increased in DF. It is in accordance with the "Intermediate Disturbance Hypothesis" which states that under intermediate levels of disturbance diversity is highest (van der Maarel, 1993).

\section{Tree layer \\ Species content}

Knowledge of tree species content is elementary to total forest biodiversity as it provides resources and habitats for almost all other forest species. In DF, 19 species (33\%) were eliminated as compared to UF. The eliminated species were represented by few individuals in UF. Among them, 7 species were represented by 1 individual each, 9 species by 2 individuals each, 2 species by 3 individuals each and 1 species by 19 individuals. It means that they are more prone to local extinction as compared to the heavily exploited species with relatively high population. The reduction in the density of some important species like Shorea robusta (by 35.7\%) and Haldina cordifolia (by 45.4\%) suggests the selective felling by local people because of their high demand in construction works, timber and other purposes. However, the convincing (existing) population of locally high demanded species in DF suggests their high regeneration capacity.

The occurrence of 13 species (22.8\%) with single individual in UF of present study is in range with the report of Sagar et al. (2003) for Indian dry forest species (18-30\% species of $>30 \mathrm{~cm} \mathrm{GBH}$ ). Upadhaya et al. (2004) reported $42-53 \%$ of the total species represented by one or two individuals in sub-tropical humid forest of Meghalaya, India. The occurrence of many species with single individual in less disturbed forests might be due to unfavorable regeneration conditions, lack of appropriate habitat or both. In spite of this, species 
composition in the undisturbed and disturbed stands of present forest is more or less similar, which may be attributed to the similar topography, soil and climatic conditions (Gautam \& Mandal, 2013) and to the sufficient movement of propagules and pollens through the landscape.

\section{Stand density}

The variation in the composition of dominant tree species and forest stand density in tropical forests of world is mainly due to variation in biogeography and habitat disturbance (Mani \& Parthasarathy, 2009). In the present study, the reduced density in DF was largely attributed to a low proportion of young trees belonging to smaller girth classes. The lower tree density could be a result of higher edge to area ratio and a subsequent increase in exposure to the physical environment. It may also be attributed to the selective cutting of straight boles of tree for use as poles by local people. The stand density of the present forest is lower, higher or comparable to some tropical forests of Nepal and India (Table 7).

Table 7. Stand density of tree species in tropical forests of Nepal and India

\begin{tabular}{lcl}
\hline Forests and localities & Density (trees/ha) & \multicolumn{1}{c}{ References } \\
\hline Tropical Plateau Sal, eastern Nepal & 580 & Mandal (1999) \\
Sal, Bhabar-Terai, Nepal & $152-264$ & Rautiainen (1999) \\
Tropical, Bardia, Nepal & 348 & Shrestha \& Jha (1997) \\
Sal, western Terai, Nepal & 220 & Timilsina et al. (2007) \\
Tropical dry evergreen, India & $771-1285$ & Anbarashan \& Parthasarathy (2013) \\
Tropical moist, eastern Nepal & $234-466$ & Present study \\
\hline
\end{tabular}

\section{Conclusions}

This study has revealed the abundance and density of ecologically as well as commercially valuable timber and non-timber forest plants in the study area. Sustainable management of forests requires holistic approach in which both timber and non-timber forest plants are managed in accordance with their ecological attributes. Moreover, the effect of forest disturbance is severe on both number of tree species (decreased by 33\%) and tree density (decreased by 50\%). To maintain the carbon sequestration capacity of the present forest, tree cutting should be banned and plantation should be done in open space. Sapling should be allowed to regenerate so that status of biodiversity would be restored.

\section{Acknowledgements}

The authors are grateful to the Head, Department of Botany and to the Campus Chief of Post Graduate Campus, T.U., Biratnagar, Nepal for providing laboratory and library facilities. The first author is grateful to the Institute of Science and Technology, Tribhuvan University, Kathmandu for Ph.D. study leave and to the University Grants Commission, Nepal for the research fellowship.

\section{References}

Anbarashan, M. \& N. Parthasarathy 2013. Tree diversity of tropical dry evergreen forests dominated by single or mixed species on the Coromandel Coast of India. Tropical ecology 54(2): 179-190.

Connell, J.H. 1978. Diversity in tropical rain forests and coral reefs. Science 199: 1302-1310. 
FAO 2011. State of the world's forests. Food and Agriculture Organization, Rome.

FRSC 1994. Deforestation in the Terai Districts 1978/79-1990/91, Forest Research and Survey Centre, Ministry of Forests and Soil Conservation, Publication Number 60, pp 9.

Gautam, T.P. \& T.N. Mandal 2013. Soil characteristics in moist tropical forest of Sunsari District, Nepal. Nepal Journal of Science and Technology 14: 35-40.

Giri, M.K. 1996. Conservation and management of biological resources in Nepal Himalaya. In: Conservation and Management of Biological Resources in Himalaya (Eds. P.S. Ramakrishnan, A.N. Purohit, K.G. Saxena, K.S. Rao \& R.K. Maikhuri). G.B. Pant Institute of Himalayan Environment and Development, Almora and Oxford and IBH Publishing Co. Pvt. Ltd. New Delhi. pp 153-161.

Hubbell, S.P. \& R.B. Foster 1983. Diversity of canopy trees in a neotropical forest and implications for conservation. In: Tropical Rain forest: Ecology and Management (Eds. S.L. Sutton, T.C. Whitmore \& A.C. Chadwick). Blackwell Scientific Publications. Oxford. pp. 25-41.

Lalfakawma, U.K. Sahoo, S. Roy, K. Vanlalhriatpuia \& P.C. Vanalalhluna 2009. Community composition and tree population structure in undisturbed and disturbed tropical semievergreen forest stands of north-east India. Applied ecology and environmental research 7(4): 303-318.

Mandal, T.N. 1999. Ecological analysis of recovery of landslide damaged Sal forest ecosystem in Nepal Himalaya (Ph.D. Thesis). Banaras Hindu University, Varanasi, India.

Mani, S. \& N. Parthasarathy 2009. Tree population and above-ground biomass changes in two tropical dry evergreen forest sites of peninsular India. Tropical Ecology 50: 249-258.

May, R.M. \& M.P.H. Stumpf 2000. Species-area relations in tropical forests. Science 290: 2084-2086.

Rautiainen, O. 1999. Spatial yield model for Shorea robusta in Nepal. Forest Ecology and Management 119: 151-162.

Sagar, R., A.S. Raghubanshi \& J.S. Singh 2003. Tree species composition, dispersion and diversity along a disturbance gradient in a dry tropical forest region of India. Forest Ecology and Management 186: 61-71.

Shrestha, K.K. \& P.K. Jha 1997. Plant diversity and evaluation of conservation measures in the Royal Bardia National Park (RBNP). A report submitted to World Wildlife Fund Nepal Program, Kathmandu, Nepal.

Shrestha, T.B., J.P.B. Lilleso, L.P. Dhakal \& R. Shrestha 2002. Forest and vegetation types of Nepal. Ministry of Forests and Soil Conservation, HMG/Nepal, Natural Resource Management Sector Assistance Programme (NARMSAP), Tree Improvement and Silviculture Component, Kathmandu, Nepal.

Timilsina, N., M.S. Ross \& J.T. Heinen 2007. A community analysis of sal (Shorea robusta Gaertn. f.) forests in the western Terai of Nepal. Forest Ecology and Management 241(1-3): 223-234.

Upadhaya, K., H.N. Pandey, P.S. Law \& R.S. Tripathi 2004. Diversity and population characteristics of woody species in subtropical humid forest exposed to cultural disturbances in Meghalaya, Northeast India. Tropical ecology 45: 303-314.

van der Maarel, E. 1993. Some remarks on disturbance and its relations to diversity and stability. Journal of Vegetation Science 4: 733-736. 